\title{
Nutrition and Gastro-intestinal Helminths in Sheep on Hill Grazing: The Effect of a Dietary Supplement on Faecal Worm- egg Counts, Worm Burden, Body-weight and Wool Production
}

\author{
By E. G. WHITE* AND G. H. CUSHNIE \\ Rowett Research Institute, Bucksburn, Aberdeenshire
}

(Received 21 September 1951)

There are many publications on the effect of nutrition on gastro-intestinal helminth infestations in sheep. In haemonchosis in lambs Whitlock, Callaway \& Jeppeson (r943) in the United States and Ross \& Gordon (1933) in Australia have shown that good diets result in lower worm-egg counts in faeces and less severe disease. Fraser $\&$ Robertson (1933) recorded the finding of larger numbers of Haemonchus contortus in poorly fed lambs than in well-fed animals grazing the same infested pasture, and Fraser, Thomson, Robertson \& George (1938) showed that experimentally infected lambs had a greater number of mature parasites at slaughter if poorly fed than if given a good diet.

It has been shown that sheep experimentally infected with Trichostrongylus spp. give less wool (Carter, Franklin \& Gordon, 1946) and show poorer weight gain and reduced utilization of protein, calcium and phosphorus than worm-free animals (Franklin, Gordon \& Macgregor, I 946).

In this country 'Taylor has repeatedly drawn attention to the importance of nutrition in parasitic gastro-enteritis in sheep and has recorded the finding of larger numbers of trichostrongylids in lambs dosed with infective larvas and kept on a diet of straw or hay than in animals given a full ration of hay and concentrates (Taylor, I943). He has also shown that heavily infected lambs on a good diet excrete in the faeces fewer worm eggs, whereas animals on a poor diet show a progressive rise in worm-egg counts (Taylor, 1943).

\section{EXPERIMENTAL}

General. Most of the work referred to deals with artificial infection or with heavy natural infections. The present investigation was designed to study the effect of natural infection in a flock of hill sheep kept under ordinary farming conditions and to see the effect on the general condition of the animals and on their faecal worm-egg counts and worm burdens of a dietary supplement given over a long period of time. One-half of the ewes and their lambs was given no supplement and served as control. There was no interference with normal flock management. Under such conditions, with the control animals on a fair diet of hill pasture and a dietary supplement of moderate size given to the others it was not expected that very large effects would be obtained, but it was hoped that examination of the whole flock over a period of many months might show a significant difference that would indicate whether dietary

\footnotetext{
- Present address: School of Veterinary Science, University of Liverpool.
} 
supplements are likely to be effective under ordinary farming conditions. An account of the seasonal changes in worm-egg counts of the ewes in $194^{6-7}$ has appeared elsewhere (Cushnie \& White, 1948).

Animals and their management. A flock of fifty Blackface ewes, about 18 months old, was purchased in October 1946 and was divided by paired weighings into two groups of mean weights 101.8 and $10 \mathrm{r} \cdot 9 \mathrm{lb}$. The former group was given a daily supplement of $\mathrm{I} \mathrm{lb}$./ewe of a mixture of one part oats and two parts linseed-cake meal. The composition of this supplement, calculated from Woodman's (1947) tables, was about $88 \%$ dry matter, made up of protein 23 , fat 8 , soluble carbohydrate 43 , fibre 9.5 and ash $4.5 \%$. The starch equivalent, calculated from the same tables, was $69 \cdot 1$. From this figure the net energy value for fattening of the daily supplement may be put at $74^{\circ} \mathrm{Cal}$.

From October 1946 until the end of the year the ewes grazed in rotation a number of grass leys around this Institute and were mated to Blackface rams. Early in January I 947 they were transferred to Brimmond Hill, about 2 miles south-west of the Institute and reaching $870 \mathrm{ft}$. above sea-level. The flock grazed some 270 acres of rough pasture, along with whin and heather. At night the flock was brought from the hill and enclosed in a paddock of 9 acres. In the morning it returned to the hill. Mating and lambing took place on fields close to the Institute.

The lambs born of ewes given supplement shared their dams' supplement until they were weaned at about 4 months, when they received their own ration which was gradually increased until each lamb had $\mathrm{I}$ lb. daily.

No cases of clinical helminthiasis were observed and no anthelmintic treatment was given to any of the animals.

The ewes were studied over a period of 2 years and observations were made on the r 947 crop of lambs until they were about 18 months old.

Helminthological methods. Worm-egg counts were made once a week on faeces of ewes and lambs. Samples were taken directly from the rectum by the same person and counts of all the eggs of the Strongyloidea spp. were made within a few hours by a modified McMaster technique (Gordon \& Whitlock, 1939) and expressed as total no. of eggs/g faeces. Counts of Strongyloides papillosus were not included.

Total worm-counts were made on eleven ewes (six given supplement and five without) which were slaughtered in October 1948 and on the forty-three surviving lambs of the 1947 crop (twenty-three with supplement, twenty without), sent for slaughter in October 1948 at the age of about 18 months. The stomachs and intestines were tied off and brought back to the laboratory for worm counts. The abomasum and intestines were opened and the contents emptied into glass vessels. The mucous surfaces were washed with water and gently scraped and the material so obtained was added to the contents, which were then passed through a wire sieve ( 80 strands/in.) and washed with water until free from colouring matter. The material left in the sieve was transferred to a glass vessel, made up to 21 . with water, and a sample of $100 \mathrm{ml}$. was taken while the suspension was being thoroughly stirred. This sample was treated with formalin to give a final concentration of $2 \%$ formaldehyde and stored until a worm count was made and the total count calculated. This method is unsuitable for large 
parasites because of the difficulty of accurate sampling: had time permitted, it would have been preferable to have counted the large worms directly in the material in the sieve.

Body-weight and fleece weight. All animals were weighed fortnightly. Fleece weights were recorded at shearing time: there were two records for the ewes (July 1947 and June 1948) and one for the lambs (June 1948).

\section{Egg counts}

RESULTS

Ewes. The weekly faecal worm-egg counts over a period of 2 years are shown in Fig. I. In order to minimize the variation between individual animals the counts are expressed as the geometric mean of the worm eggs/g faeces/ewe at each weekly

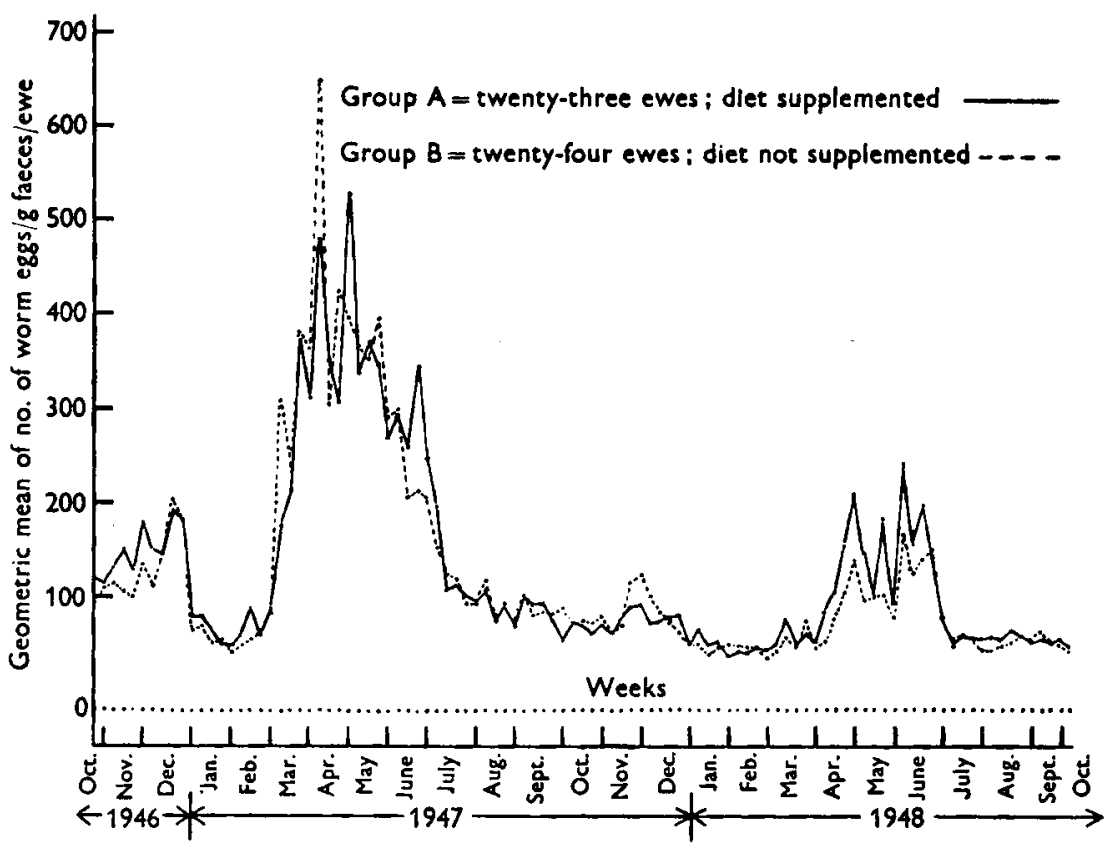

Fig. I. Weekly egg counts of ewes from October 1946 to October 1948.

sampling. Group A consisted of twenty-three ewes given supplement and group B of twenty-four animals without supplement. The remaining three ewes died during the period of observation.

The mean initial counts for the supplemented and unsupplemented groups were 135 eggs per $g(\mathrm{e} . / \mathrm{g})$ and ro7 e./g, respectively. After a small rise in November and December 1946, the levels fell sharply on 30 December to less than $100 \mathrm{e} . / \mathrm{g}$. In early March a sharp rise occurred and reached its peak in the unsupplemented ewes on I April with a mean count of $647 \mathrm{e} / \mathrm{g}$, the level in the other group being only $480 \mathrm{e} . / \mathrm{g}$. By the beginning of July 1947 the levels in both groups had fallen to just over $100 \mathrm{e} . / \mathrm{g}$ and the spring rise had ended. From July 1947 until the end of March 1948 the levels 
in both groups varied only slightly. On 6 April 1948 a second spring rise began but it was much smaller than in 1947 and, as in that year, there was little difference between the two groups of ewes. By 29 June the levels had again fallen and remained around $70 \mathrm{e} . / \mathrm{g}$ until observations ended in October 1948.

The general picture was of low resting levels and two spring rises, the first being much the larger. There was no striking difference between the supplemented and unsupplemented groups, either at their low resting levels or during the rises. Analysis of variance showed that the ratio of the geometric means of the two groups at no time reached significance and agreement between the two groups was remarkably close.

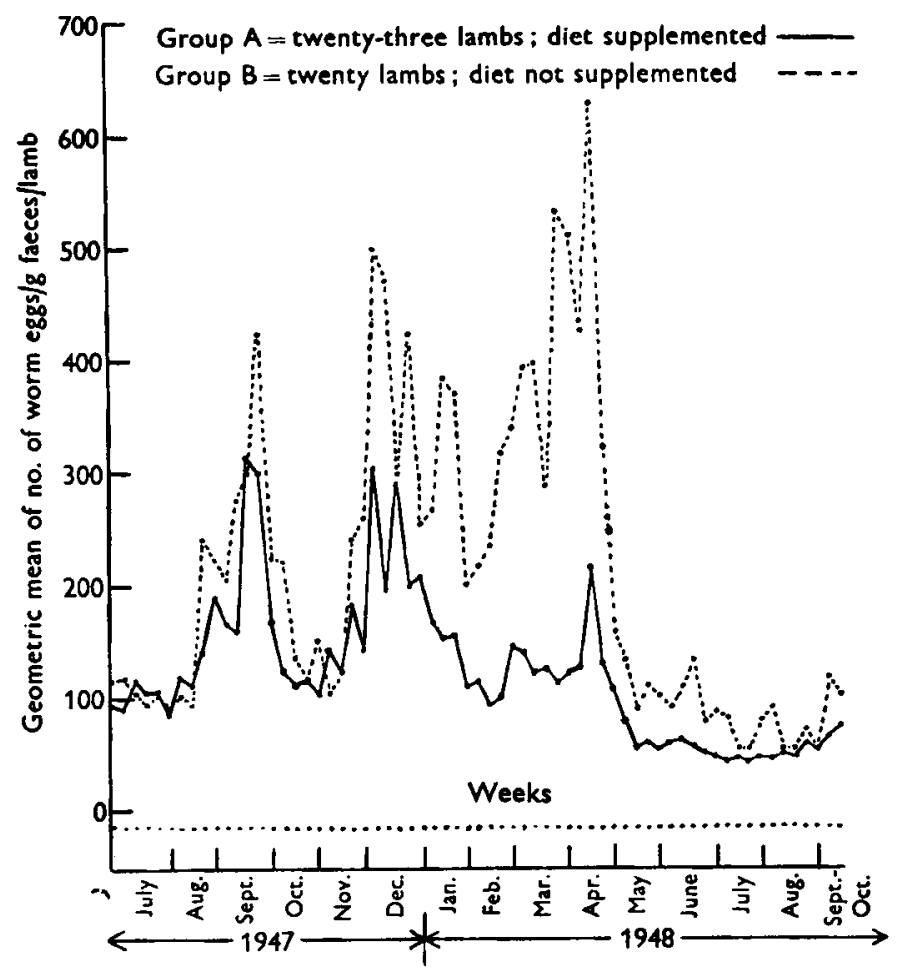

Fig. 2. Weekly egg counts of lambs born in 1947 , from July 1947 to September 1948 .

Lambs, 1947. The egg counts are shown in Fig. 2 and cover the period July 1947 to September 1948. The values are expressed as the geometric mean of weekly counts of worm eggs/g faeces/lamb. For the first 3 or 4 months after birth the egg counts were too low for the McMaster method to be used: only the counts obtained by this method have been recorded on the graph.

The initial levels were just over $100 \mathrm{e}$./g in both groups of lambs (twenty-three lambs given supplement and twenty without supplement). On 2 September 1947, a sharp rise occurred in both groups and reached its maximum on 30 September with a count of $430 \mathrm{e} . / \mathrm{g}$ in the group without supplement, but with one only just exceeding $300 \mathrm{e} . / \mathrm{g}$ in the supplemented group. Both groups had fallen to $100-150 \mathrm{e} / \mathrm{g}$ by the 
end of October. At the end of November the levels in both groups began to rise steeply. The unsupplemented group reached a maximum of $505 \mathrm{e}$./g on 9 December and did not fall to $100 \mathrm{e}$./g until 5 months later, by which time a large spring rise in March-April had taken place, with a maximum level of over $600 \mathrm{e} . / \mathrm{g}$. In contrast, the group receiving supplement recovered from the rise by January 1948 , falling to a level of about $100 \mathrm{e} / \mathrm{g}$ and showed only a very small spring rise in April. The increasing peaks of the unsupplemented group were in striking contrast to the falling peaks of the group given supplement. By the end of May 1948 both groups had levels of $55^{-}$ r $45 \mathrm{e}$./g and remained within these limits until the animals were sent for slaughter in October 1948 .

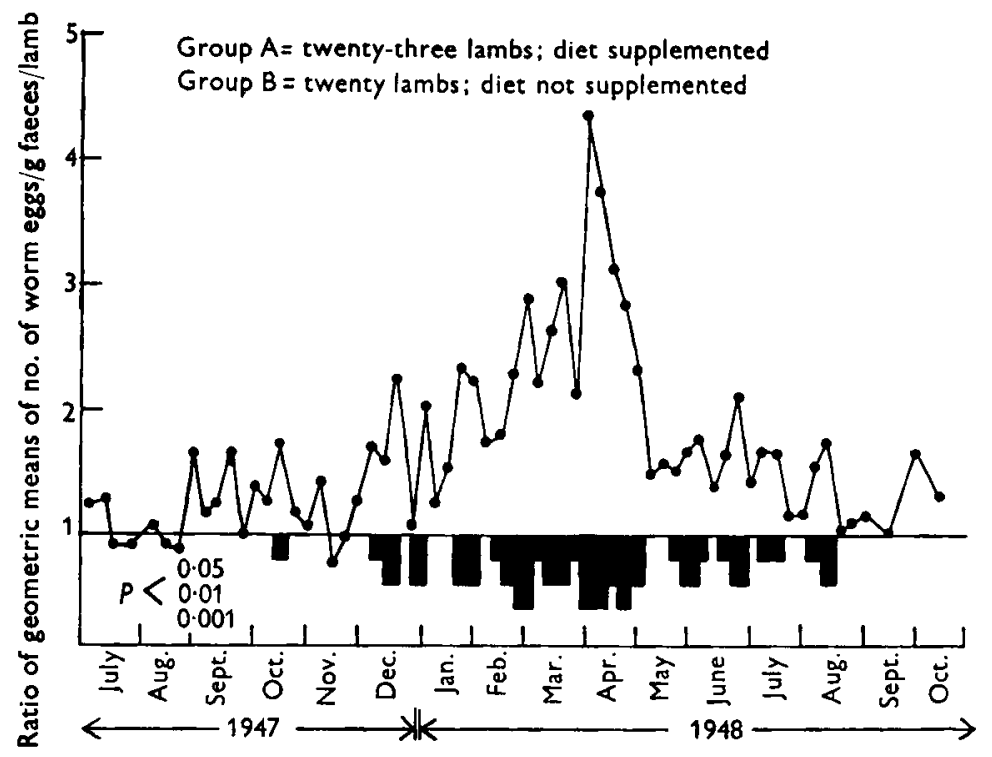

Fig. 3. Graph showing ratio of geometric means of weekly egg counts of the group of lambs without supplement to those of the group given supplement (horizontal line at I on ordinate). The values of $P$, indicating statistical significance, are given below the horizontal line.

Between 25 November 1947 and the end of the period of observation almost a year later the faecal worm-egg count of the supplemented group at no time reached that of the group without supplement. At the low resting levels the difference between the groups was small but during the three rises the differences were 105,265 and $410 \mathrm{e} . \mathrm{g}$, respectively.

This difference between the worm-egg counts in the two groups is shown in Fig. 3 in which the ratio of the geometric means of the egg counts is given. Nought in the McMaster count was for convenience replaced by 50 in order to facilitate the calculations, and this has reduced the significance at times when egg counts were low. Analysis of variance showed that the difference between the levels in the two groups was significant throughout most of the period between December I947 and August 1948. During the spring rise of 1948 significance was at a high level $(P<0.001)$ on several occasions and many weekly counts gave levels of $P<0.05$ or 0.01 . 


\section{Total worm counts}

Ewes. The total worm counts for six ewes given supplement and five without are shown in Table I. The number of animals was too small to justify any conclusions, but it is of interest to observe the low worm burden. Nematodirus was not found in any animal and Trichostrongylus spp. were present in only four: in the lambs these two species accounted for most of the worm burden. The remaining thirty-six ewes were not slaughtered.

Table r. Total worm counts (calculated) in ewes

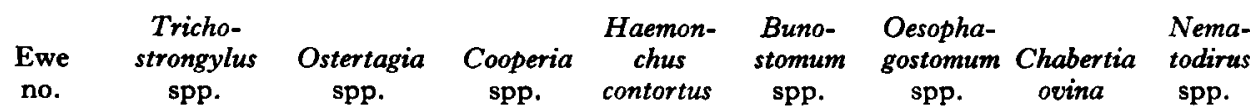

Ewes given dietary supplement

$\begin{array}{lrr}249 & 0 & \\ 251 & 640 & 10 \\ 228 & 110 & 940 \\ 220 & 0 & 20 \\ 224 & 120 & 360 \\ 255 & 0 & 20 \\ \text { Total } & 870 & 1440\end{array}$

$\begin{array}{rrrr}0 & 40 & 0 & 0 \\ 100 & 200 & 0 & 40 \\ 940 & 0 & 0 & 80 \\ 20 & 20 & 0 & 0 \\ 360 & 0 & 0 & 20 \\ 20 & 0 & 0 & 0 \\ 440 & 260 & 0 & 140\end{array}$

$\begin{array}{lll}0 & 0 & 0 \\ 0 & 0 & 0 \\ 0 & 0 & 0 \\ 0 & 0 & 0 \\ 0 & 0 & 0 \\ 0 & 0 & 0 \\ 0 & 0 & 0\end{array}$

Ewes given no supplement

$\begin{array}{lrr}260 & 0 & 0 \\ 211 & 0 & 120 \\ 246 & 100 & 220 \\ 259 & 0 & 0 \\ 225 & 0 & 220 \\ \text { Total } & 100 & 560\end{array}$

$\begin{array}{rrr}0 & 0 & 0 \\ 0 & 0 & 60 \\ 20 & 0 & 100 \\ 0 & 0 & 40 \\ 40 & 0 & 20 \\ 60 & 0 & 220\end{array}$

Lambs. Worm counts were low (Table 2). The relative numbers of the different species of helminths were similar in the two groups. Trichostrongylus, Nematodirus and Ostertagia were the most numerous species. Haemonchus was found in only one lamb. Bunostomum was a common parasite. More worms were found in the group of twenty lambs not given supplement than in the supplemented group of twenty-three lambs, but individual differences were marked and the difference between the two groups was not statistically significant.

\section{Body-weight}

There was no significant difference between the ewes in the two groups. At birth the mean weight of the lambs in the group from ewes given supplement was $6.63 \mathrm{lb}$. and of the lambs from control ewes $6 \cdot \mathrm{I} \mathrm{I} \mathrm{lb}$. Lambing took place over a period of about I month (March to April 1947) and because of the variation in ages of the lambs the statistical test of body-weight gains was restricted to the last three fortnightly weighings before slaughter in October 1947, by which time the slight variation in lambing dates could be ignored. Table 3 gives the mean of the last three weighings and shows that the difference in favour of the group receiving supplement is significant at a level of $0.1 \%(P<0.001)$, the mean difference in weight being $15.8 \mathrm{lb}$. 
Table 2. Total worm counts (calculated) in lambs

\begin{tabular}{|c|c|c|c|c|c|c|c|c|}
\hline $\begin{array}{c}\text { Hogg } \\
\text { no. }\end{array}$ & $\begin{array}{l}\text { Tricho- } \\
\text { strongylus } \\
\text { spp. }\end{array}$ & $\begin{array}{l}\text { Ostertagia } \\
\text { spp. }\end{array}$ & $\begin{array}{c}\text { Cooperia } \\
\text { spp. }\end{array}$ & $\begin{array}{c}\text { Haemon- } \\
\text { chus } \\
\text { contortus }\end{array}$ & $\begin{array}{c}\text { Buno- } \\
\text { stomtum } \\
\text { spp. }\end{array}$ & $\begin{array}{c}\text { Oesopha- } \\
\text { gostomum } \\
\text { spp. }\end{array}$ & $\begin{array}{c}\text { Chabertia } \\
\text { ovina }\end{array}$ & $\begin{array}{c}\text { Nema- } \\
\text { todirus } \\
\text { spp. }\end{array}$ \\
\hline \multicolumn{9}{|c|}{ Hoggs given dietary supplement } \\
\hline 402 & 1080 & $x 60$ & ० & $\circ$ & 40 & 40 & 40 & 1980 \\
\hline 403 & 600 & 20 & 40 & 0 & 20 & 40 & 0 & 20 \\
\hline 405 & 20 & r8o & 0 & 0 & 20 & 0 & 0 & 0 \\
\hline 406 & o & 480 & 40 & $\circ$ & 20 & o & $\circ$ & 0 \\
\hline 416 & I 80 & 80 & 0 & $\circ$ & 40 & $\circ$ & 0 & $\mathbf{0}$ \\
\hline 417 & 40 & 80 & 20 & $\circ$ & 0 & ○ & 0 & 520 \\
\hline 420 & 40 & 300 & 0 & 0 & 0 & 0 & 0 & 0 \\
\hline 425 & 0 & 0 & 0 & 0 & 20 & 0 & 0 & 0 \\
\hline 426 & 1140 & 60 & 0 & 0 & 0 & 0 & 0 & 0 \\
\hline 429 & 360 & 40 & 20 & 0 & 40 & 0 & 0 & 20 \\
\hline 432 & 320 & 440 & 40 & 0 & 0 & 0 & 0 & 0 \\
\hline 433 & 80 & 20 & 80 & 0 & 40 & 0 & 0 & 0 \\
\hline 435 & 20 & 60 & 20 & 0 & 0 & 0 & 0 & 0 \\
\hline 436 & 0 & 320 & 60 & 0 & 0 & 0 & 0 & 0 \\
\hline 442 & 160 & 420 & 0 & 0 & 20 & 0 & 0 & 0 \\
\hline 450 & 120 & 20 & 40 & 0 & 0 & 20 & 0 & 0 \\
\hline $45 I$ & 300 & 60 & 80 & 0 & 0 & 0 & 0 & 0 \\
\hline 453 & 240 & 0 & 40 & 0 & 40 & 0 & 0 & 0 \\
\hline 454 & 480 & 800 & 20 & 0 & 0 & 20 & 0 & 20 \\
\hline 459 & 120 & 540 & 0 & 0 & 60 & 0 & 0 & 20 \\
\hline 465 & 280 & 0 & 40 & 0 & 0 & 0 & 0 & 0 \\
\hline 469 & 120 & 20 & 0 & 0 & 0 & 40 & 0 & 0 \\
\hline 470 & 780 & 40 & 0 & 0 & 20 & 0 & 0 & 0 \\
\hline Total & 6480 & 4140 & 540 & 0 & 380 & 160 & 40 & 2580 \\
\hline
\end{tabular}

Hoggs given no supplement

$\begin{array}{lrrrrrrrr}412 & 0 & 240 & 0 & 0 & 20 & 0 & 0 & 0 \\ 413 & 220 & 980 & 0 & 0 & 0 & 0 & 0 & 0 \\ 419 & 2580 & 100 & 0 & 0 & 20 & 0 & 0 & 4840 \\ 421 & 0 & 20 & 0 & 0 & 20 & 0 & 0 & 0 \\ 422 & 740 & 180 & 0 & 0 & 0 & 0 & 0 & 0 \\ 423 & 1600 & 420 & 0 & 0 & 40 & 0 & 0 & 1580 \\ 424 & 100 & 40 & 0 & 0 & 0 & 0 & 0 & 0 \\ 427 & 1760 & 2100 & 120 & 40 & 20 & 0 & 0 & 1240 \\ 430 & 60 & 200 & 0 & 0 & 40 & 0 & 0 & 0 \\ 437 & 220 & 60 & 40 & 0 & 40 & 0 & 0 & 20 \\ 439 & 680 & 60 & 0 & 0 & 40 & 0 & 0 & 0 \\ 441 & 40 & 40 & 80 & 0 & 0 & 0 & 0 & 0 \\ 445 & 40 & 0 & 0 & 0 & 20 & 0 & 0 & 0 \\ 446 & 1420 & 200 & 60 & 0 & 0 & 0 & 0 & 0 \\ 447 & 860 & 0 & 0 & 0 & 0 & 0 & 0 & 0 \\ 448 & 860 & 120 & 20 & 0 & 100 & 0 & 0 & 0 \\ 456 & 320 & 760 & 40 & 0 & 40 & 20 & 0 & 1080 \\ 457 & 80 & 20 & 80 & 0 & 40 & 0 & 0 & 0 \\ 464 & 240 & 360 & 0 & 0 & 20 & 0 & 0 & 4960 \\ 471 & 320 & 40 & 20 & 0 & 0 & 0 & 0 & 0 \\ \text { Total } & 12,140 & 5940 & 460 & 40 & 460 & 20 & 0 & 13,720\end{array}$

\section{Fleece weight}

Mean fieece weights for the ewes for shearings in 1947 and 1948 , and for both years together, are shown in Table 4 , also the weights for the 1948 shearing of the lambs born in 1947. 
Both the ewes and the lambs showed a significant increase in fleece weight in the groups receiving supplement. The highest level of significance was in the lambs and in the 1947 fleece of the ewes $(P<0.001)$.

Table 3. Mean body-weight of lambs

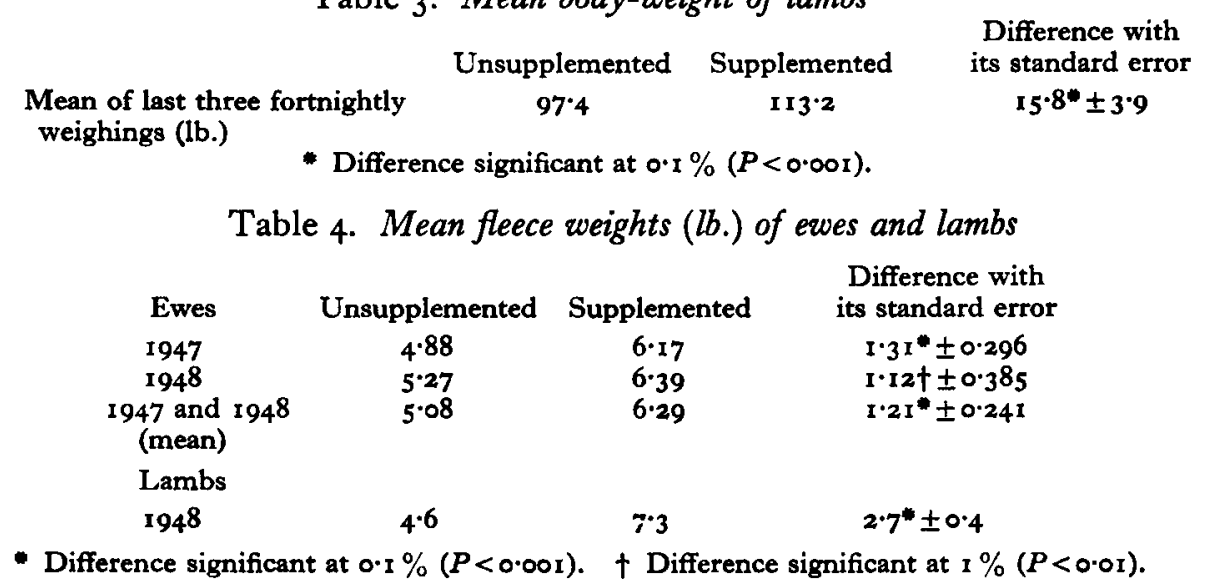

\section{DISCUSSION}

The experiment was carried out on a small flock of hill sheep kept under normal conditions of hill farming, using a breed well able to support itself and to produce lambs and wool under such conditions. No clinical symptoms of helminthiasis were observed; faecal worm-egg counts and worm counts were low and the control ewes and lambs maintained reasonable weight gains. Under such conditions a dietary supplement could not be expected to produce spectacular effects, and it is not surprising that no significant effect of the supplement could be demonstrated in the helminthological picture of the ewes which were already 18 months old when purchased.

The lambs given a daily dietary supplement showed striking differences in faecal worm-egg counts, body-weight and wool production, but not in total worm burden. The altered pattern of the weekly faecal worm-egg counts, with their higher levels and more pronounced peaks, in the control lambs suggests that the nutrition of lambs has a marked effect on egg production, especially during the spring rise and other seasonal rises.

The spring rise of the lambs given no supplement was about equal to that of the ewes in 1947, whereas that of the lambs receiving supplement was more like that of the ewes in the 2 nd year of the experiment (1948). It is clear that the dietary supplement was associated with the reduced egg excretion of the lambs: the cause of the reduced spring rise in both groups of ewes in 1948 might be age resistance or specific immunity.

The cause of the spring rise is not known.* It might be caused by: $(a)$ increased egg production of mature parasites already present; $(b)$ development to maturity of

- Note added in proof. Since this paper was submitted for publication. Morgan, Parnell \& Rayski (1951, 1952) have found that the spring rise in egg counts in Scottish hill sheep is not due to larvas that have remained dormant in the abomasum and intestine throughout the winter but to the ingestion of infective larvas during March and April. 
parasites that have been lying dormant in the mucosa; $(c)$ ingestion of fresh infective larvas. All three causes may be concerned. The third possibility $(c)$ is unlikely because it necessitates the assumption that infective larvas are ingested in January to March when the temperature is most unfavourable to their survival outside the host. The lower resistance of animals at the end of the winter may well favour increased egg production of mature worms already present and also the development to maturity of immature forms that have lain inactive in the mucosa. Morgan, Parnell \& Rayski (1950) suggest that excessive rain or snow favours high worm-egg counts in spring. If this is so it is not surprising that the high spring rise in the ewes should have occurred in 1947 , for the winter of $1946-7$ was a notoriously hard one, snow lay on the ground for some weeks and the temperature rarely rose above freezing-point (Cushnie \& White, 1948).

Fig. 2 shows that the difference in worm-egg counts between the group of lambs given supplement and the control group became progressively greater over the series of three seasonal rises in worm-egg excretion. The difference was greatest in March and April 1948 , the period of the spring rise. Since the lambs had access to supplement from birth it is difficult to explain why its effect should appear to have been greatest some ro months later when the lambs had already shown two seasonal rises in wormegg counts. It would seem that the spring rise is the one most influenced by diet and is caused by a general rise in worm-egg production in spring due to the low level of resistance at the end of the winter. The other seasonal rises, in contrast, may be caused by particular species of helminths and be related to the ingestion of large doses of infective larvas from the pasture. In May and June 1948 , when the temperature had become favourable to larval development and survival, the worm-egg counts of both groups of lambs fell steeply. It may be that warm weather and a good growth of grass have a beneficial effect on general health and resistance which is more than sufficient to offset the intake of larger doses of infective larvas. Recent work on the antibody response in natural worm infestations in sheep (Stewart, 1950) suggests that a fall in the egg count is accompanied by a rise in circulating antibody, an indication of the part which immunity may play in determining the level of the egg count.

It is likely that the three peaks in the worm-egg counts of the lambs in $1947^{-8}$ were caused by different species of parasite. Examination of larvas obtained from faecal cultures, and of species of adult worms obtained at autopsy at different times of the year support this view, although the helminthological picture of individual animals within a flock examined at any one time varies widely. Weekly worm-egg counts of a whole flock indicate general trends of egg counts, in spite of wide variations between individual animals. Not all the ewes and lambs showed the rises in worm-egg count shown on the graph of mean egg counts; some animals maintained a uniformly low count throughout the period of observation. It would seem that each animal has its own pattern of worm population and egg excretion, but that study of a sufficiently large number of animals in a flock will show a general trend over a period of weeks or months. Examination of total worm counts shows a variation within a flock that is even greater than with egg counts and is of significance only when large numbers of parasites are present. 
Elimination of adult worms in the faeces was not investigated. Few worms were noticed among the hundreds of faecal samples examined. Tetley (I949) states that expulsion of adult worms is associated with rapid falls in egg counts and records the expulsion of some 45,000 worms from a lamb over a period of 30 weeks. Whether such a phenomenon follows the spring rise is worth investigation.

These observations show that the worm-egg count in lambs can be reduced and the spring rise almost prevented by the use of a simple daily dietary supplement. A weekly supplement might be adequate and would be more likely to be of practical value. The cost of the supplement was twice the value of the extra wool and mutton it produced. Supplement for half the year (winter only) would be an economic possibility and might do all that is needed. The reduction of worm-egg counts is of value in reducing contamination of pastures. It is of interest that in spite of the use of a 9-acre field every night by the flock for 2 years, with the probable establishment of a high level of infective larvas on the pasture, worm counts and egg counts remained low. Continual grazing kept the grass short and hardly a square foot of the field was free from sheep faeces.

The effect of the supplement on body-weight and fleece weight in the lambs was considerable and showed that the increased return in meat and wool that can follow an improved diet is worth consideration. It is probable that with heavier parasite levels the supplement could have a greater effect on the worm picture. Whether viewed in terms of increased production of meat and wool or as a contribution to reducing faecal worm-egg excretion and contamination of pastures, the use of a dietary supplement has much to recommend it.

\section{SUMMARY}

I. Half of a flock of fifty Blackface ewes on hill grazing, receiving a daily supplement of I lb. of a mixture of one part ground oats and two parts linseed-cake meal, gave wool yields significantly more than animals in the other half, receiving no supplement. No significant effect on body-weight, worm burden or weekly faecal worm-egg counts was observed.

2. Lambs of this flock of ewes, given access to the supplement from the time of birth and receiving increasing amounts up to $\mathrm{I} \mathrm{lb}$. daily after weaning, had reduced faecal worm-egg counts, smaller seasonal rises in worm-egg production and highly significant increases in body-weight and wool production as compared with lambs not receiving supplement.

3. Throughout the period of the experiment, which lasted for 2 years with the ewes and 18 months with the lambs, faecal worm-egg counts and total worm counts were low and no signs of clinical helminthiasis were observed.

The authors are indebted to $\mathrm{Mr} \mathrm{W}$. Thomson and his staff at this Institute for the husbandry of the animals and for the fleece and body-weight records and to Mr M. H. Quenouille of Marischal College, University of Aberdeen, for the statistical analysis. 


\title{
REFERENCES
}

Carter, H. B., Franklin, M. C. \& Gordon, H. McL. (I946). F. Coun. sci. industr. Res. Aust. 19, 6 I. Cushnie, G. H. \& White, E. G. (1948). Vet. Rec. 60, 105.

Franklin, M. C., Gordon, H. McL. \& Macgregor, C. H. (1946). F. Coun. sci. industr. Res. Aust. 19, 46. Fraser, A. H. H. \& Robertson, D. (1933). Emp. F. exp. Agric. r, 17.

Fraser, A. H. H., Thomson, W., Robertson, D. \& George, W. (1938). Emp. F. exp. Agric. 6, 316.

Gordon, H. McL. \& Whitlock, H. V. (1939). F. Coun. sci. industr. Res. Aust. 12, 50.

Morgan, D. O., Parnell, I. W. \& Rayski, C. (1950). F. Helminth. 24, 101.

Morgan, D. O., Parnell, I. W. \& Rayski, C. (1951). F Helminth. $25,177$.

Morgan, D. O., Parnell, I. W. \& Rayski, C. (r952). Scot. Agric. 32, 46.

Ross, I. C. \& Gordon, H. McL. (1933). Aust, vet. F. 9, 100.

Stewart, D. F. (1950). Aust. F. agric. Res. I, 427.

Taylor, E. L. (1943). Vet. Rec. 55, I 17.

Tetley, J. H. (1949). Bull. Dep. Sci. industr. Res., N.Z., no. 96.

Whitlock, J. H., Callaway, H. P. \& Jeppeson, Q. E. (1943). F. Amer. vet. med. Ass. 102, 34.

Woodman, H. E. (1947). The Composition and Nutritive Value of Feeding Stuffs. Ministry of Agriculture and Fisheries, 2nd ed. (revised). London: H.M. Stationery Office.

\section{Observations on the Vitamin Metabolism of the Common Fowl}

\section{The Effects of Oestrogen and Progesterone Injections in Immature Pullets on the Riboflavin Content of the Magnum}

\author{
By W. BOLTON \\ Poultry Research Centre, West Mains Road, Edinburgh 9
}

(Received 28 September 195I)

Riboflavin exists in the body of the fowl as the free vitamin, as flavin-mononucleotide and as flavin-adenine-dinucleotide. When a bird is about to ovulate, the amount of free riboflavin in the magnum rises to about $40 \%$ of the total vitamin present; after the egg has passed through the magnum and received its layers of albumen, the amount of free riboflavin in the magnum falls to about $30 \%$ of the total vitamin present. This decrease in free riboflavin content is approximately equal to the amount in the albumen of the eggs laid (Bolton, I952).

The fluctuations in the quantity of free riboflavin in the magnum are most likely controlled by the endocrine system, probably by ovarian hormones. Fraps, Hooker \& Forbes (1948) found progesterone in the blood plasma of laying hens and suggested that this hormone was of ovarian, and most likely follicular, origin. Hertz, Dhyse \& Tullner (1949) showed that, while the biotin content of the blood serum of chicks was increased about fivefold by stilboestrol treatment, no avidin was formed in the oviduct. The simultaneous injection of stilboestrol and progesterone evoked both an increase of biotin in the blood serum and formation of avidin in the oviduct, thus suggesting that progesterone is involved in the secretion of egg albumen.

It is known (Common \& Bolton, 1946; Common, Rutledge \& Bolton, 1947-8; Common, Bolton \& Rutledge, I947-8) that injections of oestradiol dipropionate will increase the serum-riboflavin concentration of immature pullets about fifteenfold and (Bolton, $195^{\circ}$ ) that this increase is almost entirely due to an increase in free riboflavin. 